\title{
Treatment of soybean seeds to control pathogenic fungi and maintain physiological quality
}

\author{
Tratamento de sementes de soja para controle de fungos patogênicos e \\ manutenção da qualidade fisiológica
}

\begin{abstract}
Gabriela GABAN ${ }^{1}$; Jacqueline Alves Santana RODRIGUES ${ }^{1}$; Givanildo Zildo da SILVA 2 ; Carla Gomes MACHADO ${ }^{3}$; Luciana Celeste CARNEIRO ${ }^{3}$; Simério Carlos Silva CRUZ $^{3}$

${ }^{1}$ Engenheira Agrônoma e Mestranda, Universidade Federal de Goiás - UFG, Campus Jatobá, Jataí, GO, Brasil. gabrielagaban@gmail.com; jack14agro@hotmail.com

2 Autor para correspondência. Engenheiro Agrônomo, Professor, Universidade Federal de Goiás - UFG, Campus Jatobá, Jataí, GO, Brasil. givanildozildo@gmail.com

${ }^{3}$ Engenheiros Agrônomos, Professores, Doutores, Universidade Federal de Goiás - UFG, Campus Jatobá, Jataí, GO, Brasil. carlagomesmachado@gmail.com; luciana.celeste.carneiro@gmail.com; simerio@ufg.br
\end{abstract}

Recebido em: 09-06-2020; Aceito em: 30-06-2020

\begin{abstract}
This study evaluates fungicide and insecticide treatments regarding the physiological quality of seeds inoculated with Fusarium sp., Phomopsis sojae, and Colletotrichum truncatum. The Laboratory of Plant Pathology of the Federal University of Goiás (UFG) - Regional Jataí provided the pathogens. We performed the tests of seed physiological quality, germination, and vigor at the Seed Laboratory of UFG. We evaluated the following treatments for each fungus: two controls (uninoculated seeds; untreated inoculated seeds); application of mandestrobin, inpyrfluxan and clothianidin, alone and in combination; and application of two commercial products: Standak Top ${ }^{\circledR}$ and Maxim XL ${ }^{\circledR}$. For significant effects, we compared the means using the Scott-Knott test at $5 \%$ probability. Treating soybean seeds with mandestrobin + clothianidin; inpyrfluxan + clothianidin; inpyrfluxan + clothianidin + mandestrobin; or fipronil + thiophanate-methyl + pyraclostrobin (Standak Top ${ }^{\circledR}$ ) was effective in controlling Fusarium $\mathrm{sp}$. without affecting the physiological quality of seeds. Treating seeds with the active ingredients alone or in combination was not effective in controlling Phomopsis sojae and Colletotrichum truncatum, significantly decreasing the physiological quality of soybean seeds.
\end{abstract}

Additional keywords: Colletotrichum truncatum; Fusarim sp.; Glycine max; Phomopsis sojae; phytosanitary products.

\begin{abstract}
Resumo
Objetivou-se avaliar os tratamentos de fungicidas ou inseticidas na qualidade fisiológica das sementes inoculadas com Fusarium sp., Phomopsis sojae e Colletotrichum truncatum. Os patógenos foram obtidos no Laboratório de Fitopatologia da Universidade Federal de Goiás - Regional Jataí e os testes de qualidade fisiológica de sementes, germinação e vigor foram realizados no Laboratório de Sementes da mesma instituição. Foram avaliados os seguintes tratamentos para cada fungo: duas testemunhas (sem tratamento e sementes inoculadas) e aplicações isoladas de Mandestrobin, Inpyrfluxan, Clothianidin e combinações destes; além de dois produtos comerciais Standaktop ${ }^{\circledR}$ e Maxim $^{\circledR}$ XL. Quando houve efeito significativo, as médias foram comparadas pelo teste de ScottKnott a $5 \%$ de probabilidade. O tratamento de sementes de soja com Mandestrobin + Clathianidin, ou Inpyrfluxan + Clothianidin, ou Inpyrfluxan + Clothianidin + Mandestrobin, ou Fipronil + Tiofanatometilico + Piraclostrobina (Standak ${ }^{\circledR}$ Top) foi eficiente para o controle de Fusarium sp., não interferindo na qualidade fisiológica das sementes. O tratamento de sementes com os ingredientes ativos isolados ou em combinação avaliados não se mostraram eficientes no controle de Phomopsis sojae e Colletotrichum truncatum, diminuindo significativamente a qualidade fisiológica da semente de soja.
\end{abstract}

Palavras-chave adicionais: Colletotrichum truncatum; Fusarim sp.; Glycine max; Phomopsis sojae, produtos fitossanitários.

\section{Introduction}

Soybean (Glycine max) is the main crop in Brazilian agribusiness. A survey addressing the 2019/2020 grain harvest estimates the Brazilian soybean production at 123.2 million tons, with cultivation of 63.9 million hectares (CONAB, 2020). The rapid and uniform emergence of plants, combined with the correct use of cultural practices, are factors that contribute to an adequate crop performance in the field. In this context, using high quality seeds along with products that control the spread of harmful organisms, insects, and/or diseases is effective in ensuring performance and productivity in the field (Marcos Filho, 2015). Seed 
treatment is one of the main practices in soybean cropping, helping to maintain the quality of the seeds to be sown in the field (Coppo et al., 2017).

Among seed-transmitted pathogens, fungi are the most important not only due to the higher quantities, but also due to the damage caused both to the yield and quality of the seeds to be sown. In soybean crop there are several pathogens that impair seed quality, of which the following stand out: Phomopsis spp. (Li et al., 2017), Fusarium sp. (Weems et al., 2015), and Colletotrichum truncatum (Rogério et al., 2017).

Seed treatment, a technology of unquestionable importance for soybean implantation in the field, is a strategic tool in the integrated control of several diseases of economic impact (Goulart, 2016). However, there is a shortage of studies on the influence of insecticides on the germination and vigor of soybean seeds. In addition to the protective effect, some insecticides can provide certain physiological effects that assist in the initial growth and development of plants (Dan et al. 2012). North et al. (2016) concluded that using neonicotinoid insecticides in the treatment of soybean seeds increased yield in comparison to the treatment with fungicides only. The authors also observed more vigorous seedlings and a better establishment of the plant stand in the field. In soybean management, Zuntini et al. (2019) claim that alternating products with different modes of action or using ready mixes prolong the useful life of the product.

Thus, this work evaluates the effect of fungicide/insecticide treatments on the physiological quality of seeds inoculated with Fusarium sp., Phomopsis sojae, and Colletotrichum truncatum.

\section{Material and methods}

We initially characterized seeds of the soybean cultivar CG 7665 in terms of water content and thousand seed weight. We performed three experiments for the fungi Fusarium sp., Phomopsis sojae, and Colletotrichum truncatum in the Plant Pathology and Seed Laboratories of the Federal University of Goiás -
Regional Jataí.

We homogenized the seeds under laboratory conditions using a soil-type divider, passing them through the apparatus three times and making constant divisions until obtaining the study sample. To obtain pure seeds, we complemented the separation by manual picking, and expressed the results as a percentage (Brasil, 2009). At the end of this procedure, we determined water content by the greenhouse method at $105 \pm 3^{\circ} \mathrm{C}$ for $24 \mathrm{~h}$ (Brasil, 2009). We also determined thousand seed weight using four repetitions with eight subsamples of 100 seeds; we analyzed the values on a precision scale (Brasil, 2009).

Initially, we isolated the fungi Fusarium sp., Phomopsis sojae, and Colletotrichum truncatum separately in Petri dishes containing potato-dextrose-agar (BDA) medium, and incubated them at $25^{\circ} \mathrm{C}$ for seven days.

To obtain the colony, we followed the method of Machado et al. (2012, modified). We grew the fungi on new plates with BDA medium, at a water potential of $-0.6 \mathrm{MPa}$ (water restriction to prevent germination at the time of inoculation). We sealed the plates with plastic film and incubated them in a germination chamber at $25^{\circ} \mathrm{C}$ with a 12-hour photoperiod to promote the colonization of the culture medium by the pathogen. We obtained the pathogens from the collection of the Laboratory of Plant Pathology of UFG.

After obtaining the fungal colonies on BDA medium and previously disinfecting the seeds in a concentrated solution of $1 \%$ hypochlorite, we placed these seeds in a single layer under the colonies. The seeds and colonies remained in contact for 48 hours. After this period of inoculation, we placed the seeds to dry in trays, on sheets of filter paper, under aseptic conditions on a bench in an isolated room at room temperature. We treated these seeds according to Table 1, which describes the treatments for each fungus.

Table 1 - Description of treatments used on soybean cultivar CG 7665 seeds.

\begin{tabular}{llc}
\hline & \multicolumn{1}{c}{ Treatment } & Dose $\left(\mathrm{mL} 100 \mathrm{~kg}^{-1}\right.$ of seeds) \\
\hline T1 & Uninoculated seed & - \\
T2 & Inoculated seed & - \\
T3 & Mandestrobin (Fungicide) & 53 \\
T4 & Inpyrfluxan (Fungicide) & 26 \\
T5 & Clothianidin (Insecticide) & 100 \\
T6 & Mandestrobin + Inpyrfluxan & $53-26$ \\
T7 & Mandestrobin + Clothianidin & $53-100$ \\
T8 & Inpyrfluxan + Clothianidin & $26-100$ \\
T9 & Mandestrobin + Inpyrfluxan + Clothianidin & $53-26-100$ \\
T10 & Fipronil + Tiofanatometilico + Piraclostrobina (Standaktop $\left.{ }^{\circledR}\right)$ & 200 \\
T11 & Fludioxonil + Metalaxyl (Maxim $\left.{ }^{\circledR} \mathrm{XL}\right)$ & 100 \\
\hline
\end{tabular}


following:

After the treatments, we evaluated the

Germination test - we conducted this test in a completely randomized design, at the Seed Laboratory, with eight subsamples of 25 seeds from each treatment, totaling 200 seeds. We arranged these subsamples on Germitest ${ }^{\circledR}$ paper rolls moistened with distilled water in an amount equivalent to 2.5 times the dry weight of the substrate. We kept the subsamples in a germination chamber regulated at $25^{\circ} \mathrm{C}$. We carried out the final evaluation eight days after sowing, counting normal and abnormal seedlings and dead seeds. We interpreted the results according to RAS criteria (Brasil, 2009).

First germination count - we conducted this evaluation along with the germination test, on the fifth day after sowing (Brasil, 2009). We did not remove the seedlings on this date, keeping them until the date of the final germination test to check if they would remain normal or become abnormal due to fungus infection.

Seedling length - we conducted this evaluation along with the germination test, on the eighth day after sowing. We measured the length of normal seedlings with a centimeter ruler. We divided the measurements of normal seedlings by the total number of seedlings, expressing the results in $\mathrm{cm}$ seedling ${ }^{-1}$.

Seedling emergence in the field - we conducted this evaluation in four randomized blocks. Sowing took place in $50 \mathrm{~cm}$ beds. For that, we arranged the seeds in double rows at five $\mathrm{cm}$ depth, with 25 seeds in each row, totaling 200 seeds per treatment. We performed daily counts, computing the number of emerged seeds (cotyledons totally above ground) until stabilization. During this period, we recorded a minimum temperature of $13.3^{\circ} \mathrm{C}$, average temperature of $19.2^{\circ} \mathrm{C}$, maximum temperature of $28.4{ }^{\circ} \mathrm{C}$, and $18.0 \mathrm{~mm}$ of rainfall distributed over five days. We performed irrigation when necessary to keep the soil close to field capacity. These data were recorded by the Agrometeorological Station of UFG, Regional - Jataí.

We subjected the data to normality and homogeneity tests, transforming them $(x+1)^{1 / 2}$ when necessary; however, the averages of the variables were the originals. We performed analysis of variance using the $F$ test $(\alpha \leq 0.05)$, and compared significant means using the Scott-Knott test $(\alpha \leq 0.05)$. We used the software AgroStat ${ }^{\circledR}$ for all analyses.

\section{Results and discussion}

The seeds of the soybean cultivar CG 7665 had water content of $10.28 \%$ and thousand seed weight of $167.61 \mathrm{~g}$. Smaniotto et al. (2014) concluded that imbibition damage is higher in soybean seeds when seed moisture content is above $12 \%$, with loss due to deterioration. The moisture of the seeds of this study before treatment is below the range indicated by these authors, thus ensuring that the difference occurred due to the treatments and not due to imbibition damage or deterioration.

For percentage of germination and abnormal seedlings, treatments $7,8,9$, and 10 did not differ from the uninoculated control (treatment 1), showing that these treatments did not affect the physiological quality of seeds. In turn, treatments 3, 4, 6, and 11 behaved the opposite, not differing from treatment 2 (untreated inoculated seeds), remembering that treatment 11 is the commercial product Maxim $\mathrm{XL}^{\circledR}$. Seed treatment only with insecticide (treatment 5) showed phytotoxicity effect since it drastically reduced germination and the seedlings formed were abnormal, with atrophied primary root and absence of secondary roots (Table 2).

Table 2 - Germination (G), abnormal seedlings (AS), dead seeds (DS), first germination count (FGC), seedling emergence in the field (EF) and seedling length (SL) of soybean seeds submitted to inoculation with Fusarium sp. and treated with fungicides and insecticides.

\begin{tabular}{|c|c|c|c|c|c|c|}
\hline \multirow{2}{*}{ Treatment } & G & AS & DS & FGC & EF & \multirow{2}{*}{$\begin{array}{l}\mathrm{SL} \\
(\mathrm{cm})\end{array}$} \\
\hline & \multicolumn{5}{|c|}{ 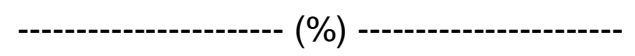 } & \\
\hline T1 - Uninoculated seed & $95 \mathrm{a}$ & $4 \mathrm{a}$ & $1 \mathrm{a}$ & $89 \mathrm{a}$ & $91 \mathrm{a}$ & $25.1 \mathrm{a}$ \\
\hline T2 - Inoculated seed & $75 b$ & $18 \mathrm{~b}$ & $7 \mathrm{~b}$ & $87 \mathrm{a}$ & $75 \mathrm{a}$ & $23.8 \mathrm{a}$ \\
\hline T3 - Mandestrobin (Fungicide) & $66 \mathrm{~b}$ & $25 \mathrm{~b}$ & $9 \mathrm{~b}$ & $84 \mathrm{a}$ & $78 \mathrm{a}$ & $24.2 \mathrm{a}$ \\
\hline T4 - Inpyrfluxan (Fungicide) & $72 b$ & $22 \mathrm{~b}$ & $6 \mathrm{a}$ & $83 a$ & $79 a$ & $21.9 \mathrm{a}$ \\
\hline T5 - Clothianidin (Insecticide) & $7 \mathrm{c}$ & $77 c$ & $16 \mathrm{c}$ & $0 \mathrm{~b}$ & $83 \mathrm{a}$ & $7.1 \mathrm{~b}$ \\
\hline T6 - Mandestrobin + Inpyrfluxan & $75 \mathrm{~b}$ & $18 \mathrm{~b}$ & $7 \mathrm{~b}$ & $81 \mathrm{a}$ & $83 \mathrm{a}$ & $22.8 \mathrm{a}$ \\
\hline T7 - Mandestrobin + Clothianidin & $83 \mathrm{a}$ & $14 \mathrm{a}$ & $3 a$ & $82 \mathrm{a}$ & $87 \mathrm{a}$ & $22.1 \mathrm{a}$ \\
\hline T8 - Inpyrfluxan + Clothianidin & $81 \mathrm{a}$ & $11 \mathrm{a}$ & $8 b$ & $80 \mathrm{a}$ & $83 \mathrm{a}$ & $22.3 \mathrm{a}$ \\
\hline T9 - Mandestrobin+ Inpyrfluxan +Clothianidin & $85 \mathrm{a}$ & $11 \mathrm{a}$ & $4 \mathrm{a}$ & $83 a$ & $83 \mathrm{a}$ & $23.5 \mathrm{a}$ \\
\hline T10 - Standaktop ${ }^{\circledR}$ & $84 a$ & $11 \mathrm{a}$ & $5 a$ & $88 \mathrm{a}$ & $86 \mathrm{a}$ & $23.8 \mathrm{a}$ \\
\hline $\mathrm{T} 11-$ Maxim $^{\circledR} \mathrm{XL}$ & $74 \mathrm{~b}$ & $17 \mathrm{~b}$ & $9 \mathrm{~b}$ & $80 \mathrm{a}$ & $74 \mathrm{a}$ & $22.0 \mathrm{a}$ \\
\hline CV (\%) & 10.6 & 32.0 & 36.2 & 5.9 & 5.8 & 13.1 \\
\hline
\end{tabular}

Means followed by the same letter do not differ from each other by the Scott-Knott test $(\alpha \geq 0.05)$. 
Gotardo et al. (2001) state that systemic insecticides are effective in controlling soil pests; however, they are likely to reduce seedling survival due to the phytotoxic effect. In addition, these products have no action on fungi, giving them the opportunity to develop, which impairs seedling performance. It is noteworthy that the germination test provides favorable conditions of temperature and humidity not only for seeds but also for fungi to develop.

Regarding the variable dead seeds, treatments $4,7,9$, and 10 did not differ from that with uninoculated seeds and, therefore, stood out in relation to the other treatments. Furthermore, treatments 2, 3, 6, 8, and 11 were inferior to the uninoculated control. However, they were superior to treatment 5 (clothianidin), which consisted of seed treatment only with insecticide. Treatment 5 had the highest percentage of dead seeds, thus confirming the phytotoxic effect of this treatment.

According to the first germination count, field emergence, and seedling length, the variable vigor behaved similarly between treatments. For this variable, all treatments were equal to the uninoculated control (treatment 1), with the exception of treatment 5. The first germination count and seedling length showed that this treatment impaired seed vigor and normal seedling development.

In the first germination count, untreated seeds inoculated with Fusarium sp. (treatment 2) did not differ from uninoculated seeds (treatment 1). Notwithstanding, the final germination count showed a statistical difference between these two treatments, thus demonstrating the increase in abnormalities in treatment 2. According to Machado et al. (2012), the effects of pathogens on seed quality are variable and noticeable during the germination process and in the subsequent stages of plant development.

Seed treatments with fungicide/insecticide combinations provided better germination and seed vigor in comparison to treatments with the products alone (treatments 3, 4, and 5) or with the combination of the two fungicides (treatment 6). This is probably due to the treatments comprehending more than one mode of action, thus increasing the spectrum of action, which is common for most commercial products on the market.

Fusarium species can survive both in the soil, through resistance structures, and in internal seed structures such as the embryo (Ramos et al., 2014). After the point of physiological maturity or during storage, the presence of pathogenic microorganisms reduces the physiological potential and the sanitary quality of seeds at a faster rate (Barbosa et al., 2013). Preventive diagnosis - before sowing - and chemical treatment of seeds are measures that help to combat Fusarium (Weems et al., 2015).

The germination test showed greater viability for treatments 7, 8, 9, and 10; and the first germination count and seedling length and field emergence pointed to greater seed vigor in these treatments, which were similar to the uninoculated control. Even though treatment 8 led to a higher percentage of dead seeds, in comparison to the control and treatments 7, 9, and 10, it remained among the best treatments. It is noteworthy that all these treatments provided a germination value higher than the minimum required for the commercialization of soybean seeds, which, according to Brasil (2013), is $80 \%$.

Seed treatments with inoculation of Phomopsis sojae and application of fungicides and insecticides (Table 3) were not effective since none of the treatments behaved similarly to the control (uninoculated seeds T1) for germination and vigor. The treatments were equal or inferior to that with untreated inoculated seeds (treatment 2), with the exception of commercial products, which were superior to treatment 2 for germination and seedling length and emergence, but with values well below the value of $80 \%$ for commercialization.

Treatments 3, 4, 5, 7, 8, 10, and 11 provided a higher percentage of abnormal seedlings, as well as the inoculated control. For the variable dead seeds, treatments 4, 6, 7, and 9 stood out negatively, providing higher percentages than the inoculated control (treatment 2). Treatments 3, 5, 8, and 11, in turn, equaled the control. Treatment 10 had the lowest percentage of dead seeds, but still with high rates, differing from the control.

According to the tests of first germination count and seedling length and emergence, seed vigor behaved similarly, with all treatments inferior to the uninoculated control. The results for field emergence were higher than the germination percentages obtained by the laboratory test for seeds only inoculated and those subsequently treated. This possibly happened because the field does not provide a controlled and favorable environment for fungi as germination chambers do. Fungi can better develop in germination chambers and, consequently, cause greater damage to the physiological quality of seeds. Moreover, soil is a complex medium with different edaphoclimatic factors and several microorganisms that can be antagonistic, hindering fungal infection. Nonetheless, even with superior results, none of the treatments matched the control or had satisfactory performance.

Studying the viability of soybean seeds with a high incidence of Phomopsis sp., Henning \& França Neto (1980) noticed that the presence of the fungus in the seed coat was the main factor responsible for low germination rates under laboratory conditions. The results of the present research can relate to an escape mechanism in which the seedling, when emerging, releases the infected integument in the soil, whereas in the standard germination test (paper roll), the integument remains in contact with the cotyledons, causing their deterioration.

In the germination and first germination count tests (Table 4), none of the treatments resembled the control (uninoculated seeds - treatment 1) for all variables. Thus, the products did not control the fungus, which impaired seed germination. 
Table 3 - Germination (G), abnormal seedlings (AS), dead seeds (DS), first germination count (FGC), seedling emergence in the field (EF) and seedling length (SL) of soybean seeds submitted to inoculation with $P$. sojae and treated with fungicides and insecticides.

\begin{tabular}{|c|c|c|c|c|c|c|}
\hline \multirow{2}{*}{ Treatment } & G & AS & DS & FGC & $\mathrm{EF}$ & \multirow{2}{*}{$\begin{array}{c}\mathrm{SL} \\
(\mathrm{cm})\end{array}$} \\
\hline & & & - (\%) - & & ------ & \\
\hline T1 - Uninoculated seed & $96 \mathrm{a}$ & $4 \mathrm{a}$ & $0 \mathrm{a}$ & $90 \mathrm{a}$ & $91 \mathrm{a}$ & $22.6 \mathrm{a}$ \\
\hline T2 - Inoculated seed & $0 \mathrm{~d}$ & $18 \mathrm{~b}$ & $82 \mathrm{c}$ & $\mathrm{Ob}$ & $25 d$ & $0.0 \mathrm{~d}$ \\
\hline T3 - Mandestrobin (Fungicide) & $0 \mathrm{~d}$ & $20 \mathrm{~b}$ & $80 c$ & $0 \mathrm{~b}$ & $32 \mathrm{~d}$ & $0.0 \mathrm{~d}$ \\
\hline T4 - Inpyrfluxan (Fungicide) & $0 d$ & $15 b$ & $85 d$ & $\mathrm{Ob}$ & $37 c$ & $0.0 \mathrm{~d}$ \\
\hline T5 - Clothianidin (Insecticide) & $0 d$ & $21 \mathrm{~b}$ & $79 c$ & $0 \mathrm{~b}$ & $27 d$ & $0.0 \mathrm{~d}$ \\
\hline T6 - Mandestrobin + Inpyrfluxan & $0 d$ & $8 \mathrm{a}$ & $92 d$ & $0 \mathrm{~b}$ & $38 \mathrm{c}$ & $0.0 \mathrm{~d}$ \\
\hline T7 - Mandestrobin + Clothianidin & $0 \mathrm{~d}$ & $15 b$ & $85 d$ & $0 \mathrm{~b}$ & $35 c$ & $0.0 \mathrm{~d}$ \\
\hline T8 - Inpyrfluxan + Clothianidin & $0 d$ & $24 \mathrm{~b}$ & $76 c$ & $0 \mathrm{~b}$ & $38 \mathrm{c}$ & $0.0 \mathrm{~d}$ \\
\hline T9 - Mandestrobin+ Inpyrfluxan +Clothianidin & $0 \mathrm{~d}$ & $9 \mathrm{a}$ & $91 d$ & $\mathrm{Ob}$ & $39 \mathrm{c}$ & $0.0 \mathrm{~d}$ \\
\hline T10 - Standaktop ${ }^{\circledR}$ & $7 \mathrm{~b}$ & $29 \mathrm{~b}$ & $64 \mathrm{~b}$ & $0 \mathrm{~b}$ & $53 \mathrm{~b}$ & $9.3 b$ \\
\hline T11 - Maxim ${ }^{\circledast} \mathrm{XL}$ & $3 c$ & $21 b$ & $76 c$ & $0 \mathrm{~b}$ & $39 \mathrm{c}$ & $5.8 \mathrm{c}$ \\
\hline CV (\%) & 22.4 & 31.3 & 7.1 & 3.3 & 9.9 & 33.2 \\
\hline
\end{tabular}

Means followed by the same letter do not differ from each other by the Scott-Knott test $(\alpha \geq 0.05)$.

Table 4 - Germination (G), abnormal seedlings (AS), dead seeds (DS), first germination count (FGC), seedling emergence in the field $(\mathrm{EF})$ and seedling length $(\mathrm{SL})$ of soybean seeds submitted to inoculation with $C$. truncatum and treated with fungicides and insecticides.

\begin{tabular}{|c|c|c|c|c|c|c|}
\hline \multirow{2}{*}{ Treatment } & $\mathrm{G}$ & AS & DS & FGC & EF & \multirow{2}{*}{$\frac{\mathrm{SL}}{(\mathrm{cm})}$} \\
\hline & \multicolumn{5}{|c|}{ 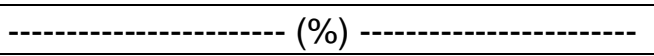 } & \\
\hline T1 - Uninoculated seed & $97 \mathrm{a}$ & $3 a$ & $0 \mathrm{a}$ & $97 \mathrm{a}$ & $90 \mathrm{a}$ & $22.2 \mathrm{a}$ \\
\hline T2 - Inoculated seed & $1 d$ & $79 d$ & $20 \mathrm{~b}$ & $41 \mathrm{c}$ & $29 c$ & $1.4 \mathrm{~d}$ \\
\hline T3 - Mandestrobin (Fungicide) & $0 d$ & $89 \mathrm{~d}$ & $11 \mathrm{~b}$ & $10 d$ & $29 c$ & $0.0 d$ \\
\hline T4 - Inpyrfluxan (Fungicide) & $1 d$ & $87 d$ & $12 b$ & $13 d$ & $41 c$ & $1.8 d$ \\
\hline T5 - Clothianidin (Insecticide) & $0 d$ & $79 d$ & $21 \mathrm{~b}$ & $24 d$ & $29 c$ & $0.0 \mathrm{~d}$ \\
\hline T6 - Mandestrobin + Inpyrfluxan & $1 d$ & $85 d$ & $14 b$ & $31 d$ & $43 c$ & $6.1 \mathrm{c}$ \\
\hline T7 - Mandestrobin + Clothianidin & $0 d$ & $85 d$ & $15 b$ & $25 d$ & $25 c$ & $0.0 d$ \\
\hline T8 - Inpyrfluxan + Clothianidin & $1 d$ & $85 d$ & $14 b$ & $18 d$ & $34 \mathrm{c}$ & $1.6 \mathrm{~d}$ \\
\hline T9 - Mandestrobin+ Inpyrfluxan +Clothianidin & $0 d$ & $82 \mathrm{~d}$ & $18 b$ & $24 d$ & $29 c$ & $0.0 \mathrm{~d}$ \\
\hline T10 - Standaktop ${ }^{\circledR}$ & $65 \mathrm{~b}$ & $25 \mathrm{~b}$ & $10 \mathrm{~b}$ & $74 b$ & $70 \mathrm{~b}$ & $19.5 \mathrm{a}$ \\
\hline T11 - Maxim ${ }^{\circledR} \mathrm{XL}$ & $33 \mathrm{c}$ & $53 \mathrm{c}$ & $14 b$ & $36 \mathrm{c}$ & $67 \mathrm{~b}$ & $13.5 b$ \\
\hline CV (\%) & 29.4 & 9.5 & 7.1 & 20.9 & 13.2 & 33.2 \\
\hline
\end{tabular}

Means followed by the same letter do not differ from each other by the Scott-Knott test $(\alpha \geq 0.05)$.

For percentage of germination, abnormal seedlings, and first germination count, treatment 10 (commercial product Standak Top ${ }^{\circledR}$ ) stood out among all treatments, followed by treatment 11 (Maxim $\left.^{\circledR}\right)$, not differing from treatment 2 (untreated inoculated seeds) in the variable first germination count.

However, even with a better result, the treatments did not meet the minimum germination (>80\%) required for commercialization of soybean seeds (Brasil, 2013). Treatments 3, 4, 5, 6, 7, 8, and 9 were inferior to the inoculated control. Therefore, the active ingredients were not effective in controlling the pathogen and impaired the early development of soybean seedlings.
The development of insecticides and fungicides aims for efficiency in the control of pests and diseases. Nevertheless, Dan et al. (2012) state that some of these products may cause effects that are still little known, capable of modifying plant metabolism and morphology, thus affecting germination.

The number of normal seedlings in the first count, on the fifth day after sowing, was high in comparison to the number of normal seedlings in the germination test on the eighth day after sowing. This is because primary infection took place on the day of the germination test, showing that the fungus impaired seedling development over time, causing seedling death by primary infection. Rogério et al. (2017) state 
that knowing the fungus species that causes soybean anthracnose is essential for success in chemical control and for producing resistant soybean cultivars in Brazil.

The pathogen can affect the plant at any stage of development and can cause seedling death; necrosis in petioles and ribs; spots on leaves, stems, and pods; total fall of pods; and total deterioration of seeds in late harvest. Losses can reach up to $100 \%$ under conditions of temperature and humidity favorable to fungal development (Silva et al., 2012). Furthermore, when present in the seeds, the pathogen can reduce germination by affecting their physiological quality, or later damage seedlings (Machado, 2012).

For the variable dead seeds, with the exception of the treatment with uninoculated seeds, all other treatments showed high mortality of seedlings, ranging from 10 to $20 \%$, with no significant difference between treatments. Therefore, the products did not control the fungus, which, in turn, led to abnormalities due to primary infection in the seedlings.

Even with lower germination than treatment 1, treatment 10 (Standak Top ${ }^{\circledR}$ ) did not provide smaller seedlings. In other words, treatment 10 did not affect seedling length, resembling the uninoculated control (treatment 1). Balardin et al. (2011) found an increase in plant length for uninoculated soybean seeds treated with Standak Top ${ }^{\circledR}$. In turn, when evaluating soybean seeds treated with several products (including Standak $\mathrm{Top}^{\circledR}$ ), Cunha et al. (2015) found no change in the physiological quality of seeds.

Regarding seedling length, treatment 11 (Maxim $\mathrm{XL}^{\circledR}$ ) and treatment 6 provided higher values in comparison to the inoculated control, but lower values in comparison to the treatments with uninoculated seeds and with Standak Top ${ }^{\circledR}$. This result indicates that the products were not effective in controlling the fungi. All other treatments $(3,4,5,7,8$, and 9$)$ were equal or inferior to the inoculated control.

Regarding seedling emergence in the field, all treatments were inferior to treatment 1 (uninoculated seeds). Seed treatments with the products Standak Top ${ }^{\circledR}$ and Maxim XL ${ }^{\circledR}$ showed a higher percentage of seedling emergence than the other treatments, which were equal or inferior to the inoculated control (treatment 2).

Hamawaki et al. (2002) point to a negative correlation between soybean seed germination and the incidence of $C$. truncatum, indicating the pathogenic effect of this fungus, which directly affects the physiological quality of seeds. In this sense, fungicides that are effective in controlling pathogens can significantly increase the physiological performance of soybean seeds.

In the present study, the high incidence of pathogens in the seeds, even after seed treatment, relates to the adopted methodology. The experiment of fungal inoculation in the seeds provided all the favorable conditions for fungal development, which would not occur so severely in the field. Several factors influence the field environment, and not all are favorable for fungi. Moreover, seed treatment protects against the action of environmental pathogens (Parisi et al., 2013). On the other hand, when inoculating only $20 \%$ of seeds with Colletotrichum truncatum, Pereira et al. (2009) found an incidence above this value. This corroborates the high degree of infection of this pathogen in soybean seeds under controlled conditions, pointing to the need for studies simulating a high incidence of infection.

\section{Conclusions}

Treating soybean seeds with mandestrobin + + clothianidin; inpyrfluxan + clothianidin; inpyrfluxan + + clothianidin + mandestrobin; or fipronil + thiophanatemethyl + pyraclostrobin (Standak Top ${ }^{\circledR}$ ) is effective in controlling Fusarium sp., without affecting the physiological quality of seeds.

Treating seeds with the active ingredients alone or in combination was not effective in controlling Phomopsis sojae and Colletotrichum truncatum, significantly decreasing the physiological quality of soybean seeds.

\section{Acknowledgements}

To the Coordination for the Improvement of Higher Education Personnel (CAPES) for granting financial support to the research, and to the "ad hoc" rapporteurs of this article for their valuable suggestions and corrections.

\section{References}

Balardin RS, Silva FDL da, Debona D, Corte GD, Favera DD, TORMEN NR (2011) Tratamento de sementes com fungicidas e inseticidas como redutores dos efeitos do estresse hídrico em plantas de soja. Ciência Rural 41:1120-1126.

Barbosa RM, Santos JS, Lopes MM, Panizzi R de C, Vieira RD (2013) Chemical control of pathogens and the physiological performance of peanut seeds. International Journal of Food, Agriculture and Environment, Helsink 11:322-326.

Brasil (2009) Regras para análise de sementes. Ministério da Agricultura, Pecuária e Abastecimento. Brasília. 399p.

Brasil (2013) Instrução Normativa ํㅡ 45, de 17 de setembro de 2013. Diário Oficial da União, Brasília, DF, 20 set. 2013. Seção 1, p. 29.

CONAB (2020) Companhia Nacional de Abastecimento. Disponível em: <https://www.conab.gov.br/infoagro/safras/graos/boletim-da-safra-de-graos/> (Acesso em 05 mar 2020).

Coppo JC, Stangarlin JR, Mioranza TM, Coltro-Roncato S, Kuhn OJ, Schwan-Estrada KRF (2017) Sanidade e germinação de sementes de soja tratadas com extratos de plantas e de fungo. Revista de Ciências Agroambientais 15:92-99. 
Cunha RP da C, Marciabela F, Schuch L, Osmar BO, Roberto $C$ de AJ, Souza J, Silva JDG da, Almeida TL de (2015) Diferentes tratamentos de sementes sobre o desenvolvimento de plantas de soja. Ciência Rural 45:1761-1767.

Dan LGM, Dan H A, Piccinin GG, Ricci TT, Ortiz AHT (2012) Tratamento de sementes com inseticida e a qualidade fisiológica de sementes de soja. Revista Caatinga, Mossoró 25:45-51.

Gotardo M, Bittencourt SRM de, Pereira LMA, Vieira RD, Gotardo Júnior JR (2001) Qualidade fisiológica de sementes de milho tratadas com diferentes inseticidas. Revista Ceres 48:511-516.

Goulart ACP (2016) Reação de cultivares de algodoeiro a Rhizoctonia solani na fase de plântula e benefícios do tratamento de sementes com fungicidas. Summa Phytopathologica 42:308-312.

Hamawaki OT, Juliatti FC, Gomes GM, Rodrigues FA, Santos VLM (2002) Avaliação da qualidade fisiológica e sanitária de sementes de genótipos de soja do ciclo precoce/médio em Uberlândia, Minas Gerais. Fitopatologia Brasileira 27:201-205.

Henning AA, França Neto J de B (1980) Problemas na avaliação de germinação de sementes de soja com alta incidência de Phomopsis sp. Revista Brasileira de Sementes 2:9-22.

Li S, Darwish O, Alkharouf NW, Musungu B, Matthews BF (2017) Analysis of the genome sequence of Phomopsis longicolla: a fungal pathogen causing Phomopsis seed decay in soybean. BMC genomics 18:688.

Machado JC, Barrocas EM, Costa LN (2012) Uso da técnica de restrição hídrica ou "Condicionamento Osmótico" em patologia de sementes. RAPP 20:37-63.

Machado JC (2012) Patologia de sementes: significado e atribuições. In: Carvalho NM, Nakagawa J (eds) Sementes: ciência, tecnologia e produção. Funep, Jaboticabal, Brasil. p.524-590.

Marcos Filho J (2015) Seed vigor testing: an overview of the past, present and future perspective. Scientia Agricola 72:363-374.
North JH, Gore J, Catchot AL, Stewart SD, Lorenz GM, Musser FR, Cook DR, Kerns DL, Dodds DM (2016) Value of neonicotinoid insecticide seed treatments in mid-South soybean (Glycine max) production systems. Journal of Economic Entomology 109:1156-1160.

Parisi JJD, Medina PF (2013) Tratamento de sementes. Instituto Agronômico de Campinas - IAC, nº 81.

Pereira CE, Oliveira JA, Rosa MCM, Oliveira GE, Costa Neto J (2009) Tratamento fungicida de sementes de soja inoculadas com Colletotrichum truncatum. Ciência Rural 39:2390-2395.

Ramos DP, Barbosa RM, Vieira BGTL, Panizzi R de C, Vieira RD (2014) Infecção por Fusarium graminearume Fusarium verticillioides em sementes de milho. Pesquisa Agropecuária Tropical 44:24-31.

Rogério F, Ciampi-Guillardi M, Barbieri MCG, Bragança CAD, Seixas CDS, Almeida AMR, Massola Junior NS (2017) Phylogeny and variability of Colletotrichum truncatum associated with soybean anthracnose in Brazil. Journal of Applied Microbiology 122:402-415.

Silva AC, Souza PE, Machado JC, Silva BM, Pinto JEBP (2012) Effectiveness of essential oils in the treatment of Colletotrichum truncatum-infected soybean seeds. Tropical Plant Pathology 37:305-313.

Smaniotto TA de S, Resende O, Marçal KAF, Oliveira DEC de, Simon GA (2014) Qualidade fisiológica das sementes de soja armazenadas em diferentes condições. Revista Brasileira de Engenharia Agrícola e Ambiental 18:446-453.

Weems JD, Haudenshield JS, Bond JP, Hartman GL, Ames KA, Bradley CA (2015) Effect of fungicide seed treatments on Fusarium virguliforme infection of soybean and development of sudden death syndrome. Canadian Journal of Plant Pathology 37:435-447.

Zuntini B, Alvarez R de CF, Theodoro G de F, Zuffo AM (2019) Efeito da adição de fungicida a misturas de triazóis e estrobilutinas no controle do míldio e da ferrugem asiática da soja. Pesquisa Agropecuaria Tropical 49:1-9. 